\title{
Comparative Energy and Exergy Analysis of Various Passive Solar Distillation Systems
}

\author{
Ragh Vendra Singh ${ }^{1}$, Rahul Dev ${ }^{2, *}$, M. M. Hasan ${ }^{1}$, G. N. Tiwari ${ }^{2}$ \\ ${ }^{1}$ Department of Mechanical Engineering, Jamia Milia Islamia, Jamia Nagar, New Delhi-110025, India. \\ ${ }^{2}$ Centre for Energy Studies, Indian Institute of Technology, Delhi, Hauz khas, New Delhi-110016, India. \\ * Corresponding author. Tel: +91 9968344470, Fax: +91 11 26591251, E-mail: rahuldsurya@yahoo.com
}

\begin{abstract}
In this communication, a comparative energy and exergy analysis of various conventional solar distillation systems has been presented. The study includes passive solar distillation systems such as single and double slope solar stills. In a single slope solar still category, three solar stills with inclination angles $15^{\circ}, 30^{\circ}$ and $45^{\circ}$ and a $15^{\circ}$ inclined single slope multi wick solar still have been considered. Whereas one double slope solar stills and one double slope multi wick solar still, both inclined at $15^{\circ}$ with east-west orientation, have been considered in double slope solar still category. The embodied energy is an important factor which depends on locally available materials and their manufacturing technologies. Materials like concrete, wood, steel etc are considered to calculate the embodied energy for the solar still equivalent to the fibre reinforced plastic after deriving the formulae. It has been found that the energy, exergy and embodied energy of single slope solar still are found higher than that of double slope solar still. Those materials which have lower thermal conductivity and low embodied energy than that of FRP such as concrete, PVC, wood can replace the FRP to save the embodied energy for similar performance. The metals have high embodied energy hence these can not be considered in terms of embodied energy despite the use of insulation.
\end{abstract}

Keywords: Solar distillation, Water purification, Energy, Exergy, Embodied energy.

\section{Nomenclature}

$A_{s}$ area of solar still

I(t) solar intensity

$\dot{E} x_{\text {evap }}$ exergy output......................W/ $m^{2}$

$\dot{E} x_{\text {in }}$ exergy input. $. W / m^{2}$

$K_{\text {material }}$ thermal conductivity of material. $\mathrm{W} / \mathrm{mK}$

$K_{\text {metal }}$ thermal conductivity of metal.......W/mK

$K_{F R P}$ thermal conductivity of FRP .........W/mK

$L \quad$ latent heat of vaporization ............. $\mathrm{kJ} / \mathrm{kg}-\mathrm{K}$ $l_{\text {material }}$ thickness of material......................m

$l_{\text {metal }}$ thickness of metal............................m

$l_{\text {Styrofoam }}$ thickness of Styrofoam..................m $\dot{m}_{e w}$ hourly distillate collected .............. $\mathrm{kg} / \mathrm{m}^{2}-\mathrm{h}$

$\dot{q}_{e w}$ heat utilized in evaporation of water...W/m $\mathrm{m}^{2}$

$T_{a}$ ambient temperature................................

$T_{s} \quad$ sun temperature....................................

\section{Introduction}

A solar distillation is a water purification technology. Saline/brackish water can be purified using solar energy. This technology works on the principles of greenhouse effect and hydrological cycle. The use of solar energy to produce potable water is a key factor in context of water \& air pollution, global warming, energy security and climate change because most of other water purification technologies use conventional sources of energy such as coal, oil, gas etc [1]. A solar still is a device used for solar distillation in which impure or saline water is fed to obtain distilled water. It is a box type structure made of some materials such as fibre reinforced plastic (FRP), wood, concrete, or steel with insulation. It is covered with a simple window glass through which the solar radiation passes to incident on the water surface. A small amount of reflection heat losses and absorption take place at the glass cover and the water. A major part of incident solar radiation is absorbed by the basin liner. This heat is transferred to the saline water by convection as top heat loss and to the ambient as bottom heat loss. Heat transfer from the water to the glass cover take place by three mechanisms: evaporation, convection and radiation. Vapour leaves most of contaminants and microbes 
through thermal diffusion on the basin liner. Further the vapour undergoes film type condensation at the inner surface of the glass cover because of inclination of glass cover, adhesion, cohesion between condensed water molecules, and gravity. The condensed water trickles down to a trough which guides it into a container placed otuside [2]. Researchers have worked to improve the performances of solar stills by suggesting its various designs, materials and operating conditions for different weather conditions. Tiwari and Tiwari [3] have reported that the yield from a single slope passive solar still may vary from 0.5 to $1.2 \mathrm{~kg} / \mathrm{m}^{2} /$ day (in winter) and 1.0 to $2.5 \mathrm{~kg} / \mathrm{m}^{2} /$ day (in summer) for Delhi, India. Tiwari [4] has found the efficiency of the single slope solar still 25.8, 19.7, $22.8 \%$ at glass cover inclinations $15^{\circ}, 30^{\circ}$ and $45^{\circ}$ respectively for the summer climatic condition of Delhi, India. Malik et al. [2] have shown that overall efficiency of a passive solar still is achieved with least water mass in the basin.

Energy and exergy analysis of solar stills have been presented by various researcher such as Dunkle [5], Cooper [6], Tsilingiris [7], and Dwivedi [8, 9] etc. A group of improved heat and mass transfer correlations in basin type solar stills has been developed by Hongfei et. al. [10]. Torchia- Núñez et al. [11] have found that for same exergy input a basin, brine and passive solar still have exergy efficiencies of $12.9 \%, 6 \%$, and $5 \%$ respectively. Dev and Tiwari [12, 13] developed the characteristic equation for single and double slope passive solar stills. In ideal solar still, the instantaneous loss efficiency is minimum (for zero depth of water mass) as analyzed by Cooper [6]. Rubio et al. [14, 15] have studied asymmetries in various temperatures and amount of distillate for a double slope passive solar still (DSPSS) and proposed mathematical models, one in terms of lumped parameters and another for controlled temperatures of glass cover and basin. Dwivedi and Tiwari [8, 9] have reported that the thermal efficiency for single and double slope solar still varies from $22.6 \%$ to $31.3 \%$ and $25.4 \%$ to $34.3 \%$ respectively at $0.01 \mathrm{~m}$ water depth. Similarly, the average exergy efficiency for single and double slope solar still is $0.65 \%$ and $0.82 \%$ respectively. The exergy efficiency of single and double slope solar still varies from 0.18 to $1.25 \%$ and 0.13 to $1.16 \%$ respectively. Tiwari and Yadav [16] have shown that a single slope distiller gives better performance than a double slope for cold climatic conditions whereas a double slope distiller gives better performance than a single slope for summer climatic conditions irrespective of either basin type or multi-wick type. It has also been reported that the concrete basin solar still gives better performance than the FRP single and double slope stills because of the probability of leakage of vapour in the FRP stills was more than for the concrete still. Sakthivel and Shanmugasundaram [17] have shown that the efficiency of single slope solar still using the black granite gravel reaches up to $52 \%$ maximum which is $8 \%$ higher than the conventional single slope solar still. Singh and Tiwari [18] have studied double effect multiwick solar stills to increase the still efficiency by utilizing the latent heat released by the vapor at first effect. Kumar and Anand [19] have studied shown that a tubular multiwick solar still gives distillate output of about $8 \%, 13 \%$, and $18 \%$ more than tubular, simple multi-wick and conventional basin type solar stills respectively.

The embodied energy is an important factor which depends on locally available materials and their manufacturing technologies. Hence, on the basis of literature survey the performance of the solar stills on the basis of energy, exergy and materials have been analyzed in this paper.

\section{Solar distillation systems}

Passive solar distillation systems such as single and double slope solar stills have been taken. In a single slope solar still category, three solar stills with inclination angles $15^{\circ}, 30^{\circ}$ and $45^{\circ}$ 
(Fig. 1a, 1b) and a $15^{\circ}$ inclined single slope multi wick solar still have been considered. Whereas one double slope solar stills and one double slope multi wick solar still both inclined at $15^{\circ}$ with east-west orientation, have been considered in double slope solar still category (Fig. 1c, 1d). All these experimental setup have been installed at Solar Energy Park, I.I.T. Delhi, New Delhi, India (28 $8^{\circ} 5^{\prime} \mathrm{N}, 7^{\circ} 12^{\prime} \mathrm{E}$, altitude $216 \mathrm{~m}$ from mean sea level). The single slope solar still works on same principle as given above.

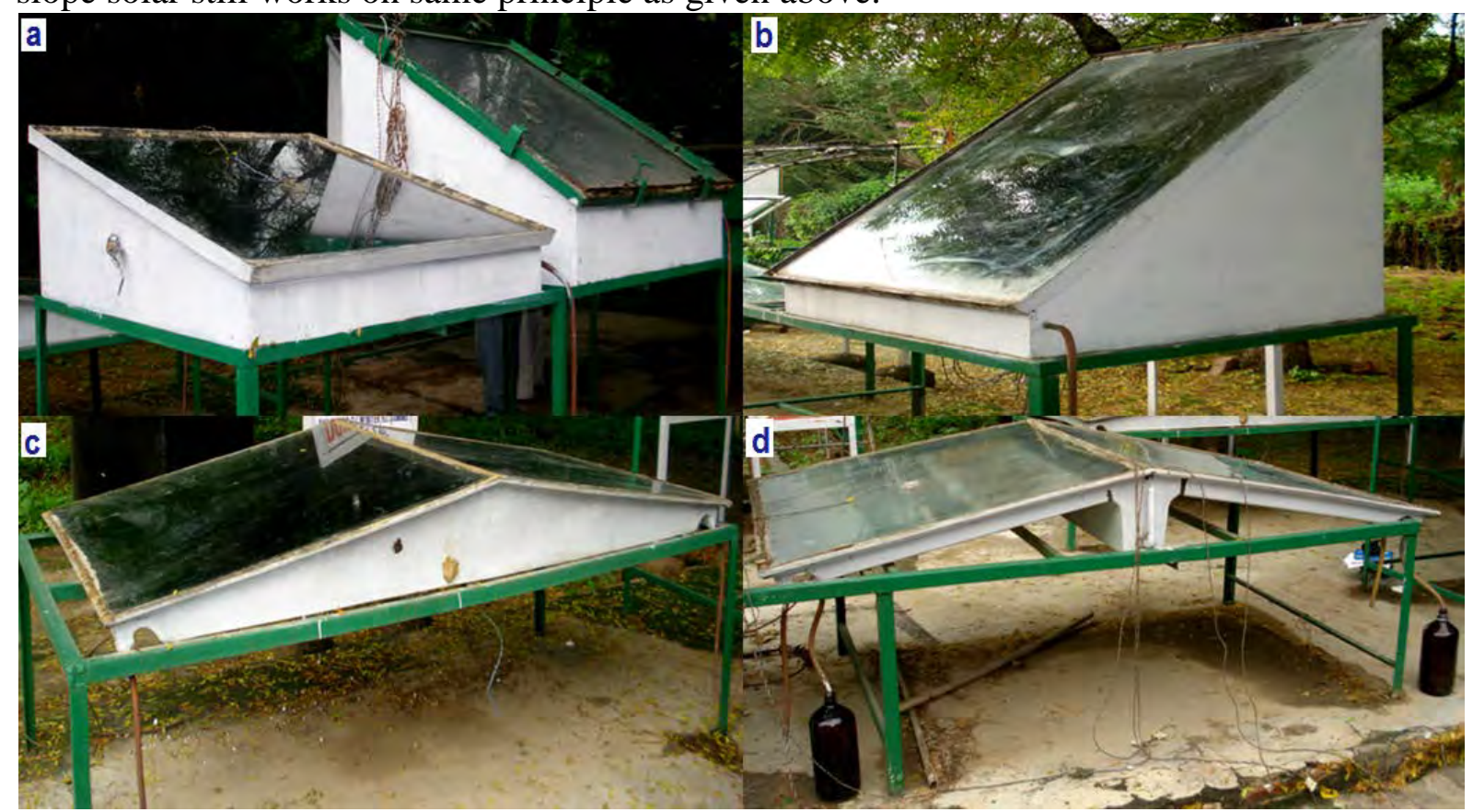

Fig. 1 Various solar stills: (a) Single slope solar still inclined at $15^{\circ}$ and $30^{\circ}$ with orientation towards south, (b) Single slope solar still inclined at $45^{\circ}$ with orientation towards south, (c) Double slope solar still inclined at $15^{\circ}$ with orientation towards east-west, (d) Double slope multi-wick solar still inclined at $15^{\circ}$ with orientation towards east-west.

A schematic diagram of double slope passive solar still has been shown in Fig. 1c. Two simple window glasses have been placed over the walls of the solar still at inclination angle $15^{\circ}$ facing east and west directions. To absorb higher amount of solar radiation, an inside surface of the solar still has been painted black in color. An inlet through the rear wall has been provided to feed the brackish/underground water in to the basin of the solar still. And two troughs are provided at inside of each short wall of the solar still to collect the distilled water. The orientation of the solar still has been kept east-west to receive solar radiation for maximum hours of sunshine. When the sun lies in the east direction then higher temperature difference occur at west side due to low glass temperature which yield higher amount of distillate at this side and vice versa except at the time of noon when both the glass covers have almost the same temperature.

In the single and double slope multi-wick solar still, water is fed from water reservoir through the multiple porous absorbers (black jute cloth) at a slow rate for fast evaporation. The saline water goes upwards due to capillary action in the jute cloths and forms a thin water layer. The solar radiation, after transmission through the glass covers, strikes this water film and heats the water. The water evaporates and condenses at the inner surface of the glass cover by releasing latent heat of vaporization. The condensed water is collected through the drainages for distilled water. A double slope multi-wick solar still, as shown in Fig. 1d, is a 
development over the single slope multi-wick solar still similar to double slope solar still, Malik et al. [2]. The specifications of these solar stills are given in Table 1.

Table 1. Design specifications of solar stills which are installed at Solar Energy Park, Centre for Energy Studies, IIT Delhi, New Delhi, India.

\begin{tabular}{clcccc}
\hline \multirow{2}{*}{$\begin{array}{c}\text { Sr. } \\
\text { No. }\end{array}$} & \multirow{2}{*}{ Specifications } & \multicolumn{4}{c}{ Single slope solar still } \\
\cline { 3 - 6 } & & \multicolumn{3}{c}{ Conventional } & Multi-wick \\
\cline { 3 - 6 } & & Type 1 & Type 2 & Type 3 & Type 4 \\
\hline 1 & Area of basin $\left(\mathrm{m}^{2}\right)$ & $1 \times 1$ & $1 \times 1$ & $1 \times 1$ & $1.1 \times 1.14$ \\
\hline 2 & Height of south wall $(\mathrm{m})$ & 0.06 & 0.15 & 0.15 & 0.06 \\
\hline 3 & Height of north wall $(\mathrm{m})$ & 0.26 & 0.74 & 1.15 & 0.25 \\
\hline 4 & Angle of inclination $\left(^{\circ}\right)$ & 15 & 30 & 45 & 15 \\
\hline 5 & Size of glass $\left(\mathrm{m}^{2}\right)$ & $1.02 \times 1$ & $1.02 \times 1.2$ & $1.02 \times 1.44$ & $1.02 \times 1.14$ \\
\hline 6 & Quantity of glass & 1 & 1 & 1 & 1 \\
\hline 7 & Putty $(\mathrm{kg})$ & 1 & 1 & 1.5 & 1 \\
\hline 8 & Paint $(\mathrm{kg})$ & 0.5 & 0.8 & 1 & 0.5 \\
\hline 9 & Iron stand $\left(\mathrm{kg}^{2}\right)$ & 5 & 20 & 18 & 17 \\
\hline 10 & Metal $(\mathrm{kg})$ & 0.2 & 0.2 & 0.2 & nil \\
\hline 11 & Jute cloth $\left(\mathrm{m}^{2}\right)$ & $\ldots$ & $\ldots$ & $\ldots$ & $4 \times 1$ \\
\hline
\end{tabular}

Double slope solar still

\begin{tabular}{clcc}
\hline & & Conventional & Multi-wick \\
\hline $\begin{array}{c}\text { Sr. } \\
\text { No. }\end{array}$ & \multicolumn{1}{c}{ Specifications } & Type 5 & Type 6 \\
\hline 1 & Area of basin $\left(\mathrm{m}^{2}\right)$ & $2 \times 1$ & $2 \times(1.1 \times 1.14)$ \\
\hline 2 & Height at ends $(\mathrm{m})$ & 0.25 & 0.05 \\
\hline 3 & Central height $(\mathrm{m})$ & 0.45 & 0.25 \\
\hline 4 & Angle of inclination at both sides $\left(^{\circ}\right)$ & 15 & 15 \\
\hline 5 & Size of glass $\left(\mathrm{m}^{2}\right)$ & $1.02 \times 1.02$ & $1.02 \times 1.14$ \\
\hline 6 & Quantity of glass & 2 & 2 \\
\hline 7 & Putty $(\mathrm{kg})$ & 3 & 3 \\
\hline 8 & Paint $(\mathrm{kg})$ & 1 & 30 \\
\hline 9 & Iron stand $(\mathrm{kg})$ & 35 & 0.5 \\
\hline 10 & Metal $(\mathrm{kg})$ & 0.2 & $8 \times 1$ \\
\hline 11 & Black Jute cloth $\left(\mathrm{m}^{2}\right)$ & & $\ldots$ \\
\hline
\end{tabular}

\section{Mathematical expressions}

Following are the mathematical expression used for the analysis of energy and exergy of considered solar still systems.

The thermal efficiency of a passive solar still can be calculated by the following formula [1]:

$$
\eta_{i}=\frac{\dot{m}_{e w} \times L}{A_{s} \times I(t) \times 3600} \times 100
$$


Exergy efficiency of a passive solar still can be calculated by the following formula [20]:

$$
\eta_{\mathrm{EX}}=\frac{\dot{\mathrm{E}} \mathrm{x}_{\text {evap }}}{\dot{\mathrm{E}} \mathrm{x}_{\text {in }}} \times 100
$$

where,

$$
\dot{\mathrm{Ex}} \mathrm{evap}_{\mathrm{i}=1}=\sum_{\mathrm{w}}^{24}\left(1-\frac{\mathrm{T}_{\mathrm{a}}}{\mathrm{T}_{\mathrm{w}}}\right) \times \dot{\mathrm{q}}_{\mathrm{ew}} \quad ; \quad \dot{\mathrm{q}}_{\mathrm{ew}}=\mathrm{A}_{\mathrm{s}} \cdot \mathrm{h}_{\mathrm{ew}} \cdot\left(\mathrm{T}_{\mathrm{w}}-\mathrm{T}_{\mathrm{gi}}\right)
$$

and

$$
\dot{E} x_{\text {in }}=\dot{E} x_{\text {sun }}=A_{s} \times I(t) \times\left[1-\frac{4}{3} \times\left(\frac{T_{a}}{T_{s}}\right)+\frac{1}{3} \times\left(\frac{T_{a}}{T_{s}}\right)^{4}\right]
$$

Equivalent thickness of materials for same performance as FRP has in case of solar still:

$$
l_{\text {material }}=\frac{K_{\text {material }}}{K_{F R P}} \times l_{F R P}
$$

Thickness of Styrofoam for insulation (when solar still is made of any metal and overall thermal conductivity is equivalent to FRP):

$$
l_{\text {Styrofoam }}=\frac{K_{\text {Styrofoam }} \cdot\left(K_{\text {Metal }} \cdot l_{F R P}-K_{F R P} \cdot l_{\text {Metal }}\right)}{K_{\text {Metal }} \cdot K_{F R P}}
$$

\section{Results and discussion}

On the basis of literature survey and Eqs. $(1,2)$ it has been observed that energy, exergy efficiencies and embodied energy of single slope solar still remain higher in comparison to that of the double slope solar still. Dev and Tiwari [12,13] have found better performances at water depth $0.01 \mathrm{~m}$ and an inclination angle $30^{\circ}$ for single slope passive solar still. They have also developed the characteristic equation of single and double slope passive solar still and suggested the sum of instantaneous gain and loss efficiencies $\left(\eta=\eta_{i}+\eta_{i L}\right)$ remain lower than maximum efficiency under ideal i.e. 60\%. Although, it can be seen that the energy efficiency can reach up to $60 \%$ maximum but because of several factor such as heat loss through vapor leakage and improper insulation, time lag in production, inclination angle, water depth etc, it does not attain such value. Similarly, the exergy efficiency which is measured for the source temperature i.e. sun temperature $6000 \mathrm{~K}$, remain always very much lower than the energy efficiency because of the energy input by the sun is not fully utilized in evaporation process of the water in the solar still.

The design specifications (Table 1), properties of various materials (Table 2 which consists of probable materials for solar still), Eqs. (3) and (4) have been used to get total embodied energy for the solar still by considering metals, concrete, PVC, wood etc. equivalent to that of 
FRP (i.e. to keep the productivity of the solar still same as of FRP). The metals have been found large thickness due to their conductivities but these metals (thickness $1 \mathrm{~mm}$ ) can be considered with insulation of Styrofoam as shown in Table 2. One can see that steel which is very high energy intensive material can not be recommended as a material to make the solar still despite the use of insulation. The thicknesses of materials such as concrete, wood, and PVC have been found very near to the thickness of the FRP. Materials such as glass window and country fired bricks have more thickness which can not be considered.

Table 2. Various manufacturing materials of solar still, their thermal conductivities, embodied energy, density and thickness with and without insulation material.

\begin{tabular}{|c|c|c|c|c|c|}
\hline 矛 & 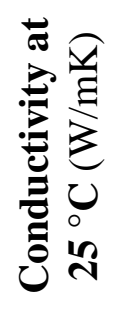 & 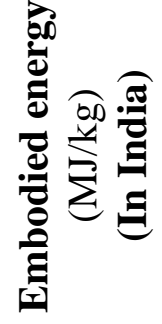 & 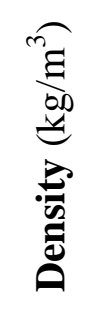 & 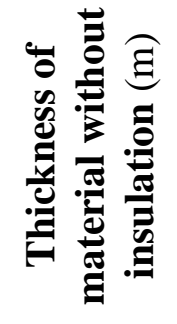 & 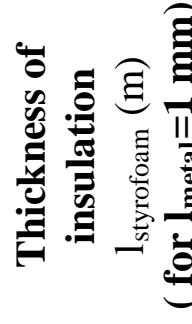 \\
\hline Copper & 401 & 112 & 8930 & 5.7 & 0.0005 \\
\hline Steel & 16.3 & 42 & 7860 & 0.232 & 0.0005 \\
\hline G.I. sheet & 80 & 50.8 & 7860 & 1.14 & 0.0005 \\
\hline Aluminium & 250 & 260 & 2600 & 3.56 & 0.0005 \\
\hline Concrete & 0.42 & 2.4 & 2200 & 0.006 & +----- \\
\hline $\begin{array}{l}\text { Country fired brick } \\
\left(22 \times 10.5 \times 6.5 \mathrm{~cm}^{3}-\right. \\
\text { delivered at } 30 \mathrm{~km})\end{array}$ & 1.31 & 7.9 & 286 & 0.018 & ------ \\
\hline Simple window glass & 0.96 & 15.9 & 2600 & 0.014 & ------ \\
\hline Polystyrene expanded & 0.03 & 117 & 640 & 0.001 & ------ \\
\hline Wood & 0.17 & 1.8 & 850 & 0.0025 & ------ \\
\hline PVC & 0.19 & 115 & 1410 & 0.003 & ------ \\
\hline $\begin{array}{l}\text { Styrofoam (for } \\
\text { insulation only) }\end{array}$ & 0.033 & 100 & 35 & ------ & ------ \\
\hline FRP & 0.351 & 92.2 & 1800 & 0.005 & ------ \\
\hline Paint & ------ & 90 & 6.1 & $\begin{array}{l}----- \\
\end{array}$ & ------ \\
\hline Jute cloth & ------ & 55 & ----- & ------ & ------ \\
\hline
\end{tabular}

The embodied energies of conventional single slope solar stills made of FRP, concrete, PVC, and wood are found and given in Table (3). The percentage increase in the embodied energy compared of other solar stills compared to that of single slope solar still inclined at $15^{\circ}$, with south wall height $0.06 \mathrm{~m}$ has also been given in same table which changes similarly irrespective of material used. The embodied energy double slope solar still, and double slope multi-wick solar still have been found to be 3070 MJ and 2323 MJ respectively when only FRP is considered. On the basis of this one can observe that the embodied energy of double slope solar stills including the multi-wick solar still are less energy intensive in comparisons to single slope solar stills (1361 MJ) and single multi-wick solar still (1495 MJ). One can see in Table 3, wood is found most suitable in terms of embodied energy but it degrades soon in comparison to other materials in terms of life. The PVC can be a better option over FRP in 
terms of embodied energy and weight. According to previous studies [3, 4], single slope solar still inclined at $30^{\circ}$ is suitable as per the latitude of Delhi. The total embodied energy for this solar still including glass, paint has been found 2587 MJ (FRP), 369 MJ (concrete), 1498 MJ (PVC), $292 \mathrm{MJ}$ (wood). Similarly for double slope multi-wick solar still inclined at $15^{\circ}$, total embodied energy including glass, paint and fabric have been found 2875 MJ (FRP), 640 MJ (concrete), 1773 MJ (PVC), 562 MJ (wood).

Table 3. Embodied energy of single slope solar still for different materials such as FRP, Concrete, Steel, Wood.

\begin{tabular}{|c|c|c|c|c|c|c|c|c|c|}
\hline \multirow[b]{2}{*}{$\begin{array}{c}\text { Solar } \\
\text { still }\end{array}$} & \multirow[b]{2}{*}{ Specifications } & \multicolumn{8}{|c|}{ Embodied energy (MJ) } \\
\hline & & $\frac{\hat{x}}{11}$ & نّ & $u_{2}^{u}$ & $\begin{array}{l}\overline{0} \\
\ddot{0} \\
\dot{3}\end{array}$ & ১० & 旁 & 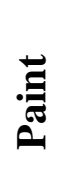 & 苞 \\
\hline \multirow{5}{*}{$\begin{array}{l}\text { Single } \\
\text { slope }\end{array}$} & $\begin{array}{l}15^{\circ} \text {, with south wall } \\
\text { height }=0.06 \mathrm{~m}\end{array}$ & 1361 & 52 & 718 & 6 & ---- & 168 & 28 & ---- \\
\hline & $\begin{array}{l}15^{\circ} \text {, with south wall } \\
\text { height }=0.15 \mathrm{~m}\end{array}$ & 1776 & 68 & 937 & 8 & 30 & 168 & 45 & ---- \\
\hline & $30^{\circ}$ & 2306 & 88 & 1217 & 11 & 70 & 208 & 73 & ---- \\
\hline & $45^{\circ}$ & 2987 & 114 & 1576 & 14 & 120 & 245 & 90 & ---- \\
\hline & $15^{\circ}$, Multi-wick & 1495 & 57 & 790 & 6.6 & 10 & 226 & 45 & 27.5 \\
\hline \multirow{2}{*}{$\begin{array}{l}\text { Double } \\
\text { slope }\end{array}$} & $15^{\circ}$ & 3070 & 117 & 1615 & 13.5 & 125 & 345 & 90 & ---- \\
\hline & $15^{\circ}$, Multi-wick & 2323 & 88 & 1221 & 10.2 & 70 & 407 & 90 & 55 \\
\hline
\end{tabular}

\section{Conclusions}

1. On the basis of above analysis and literature survey, the energy, exergy and embodied energy of single slope solar still are found higher than that of double slope solar still.

2. Those materials which have lower thermal conductivity and low embodied energy than that of FRP such as concrete, PVC, wood can replace the FRP to save the embodied energy for similar performance.

3. The metals have high embodied energy hence these can not be considered in terms of embodied energy despite the use of insulation.

4. PVC material has been found to be better in terms of embodied energy in comparison to other materials.

On the basis of above study, the similar analysis can be recommended for other materials such as glass, steel, aluminum, copper, bricks, and other advance materials, as the research in the field of materials science is progressing, to have a material of less embodied energy, light in weight, good insulator and portable in comparison to FRP as well which should be easily available in less price.

\section{References}

[1] G.N. Tiwari, A.K. Tiwari, Solar distillation practice for water desalination systems, Anshan Publication, UK Edition, 2008, pp. 1-40.

[2] M.A.S. Malik, G.N. Tiwari, A. Kumar, M.S. Sodha, Solar Distillation, Pergamon Oxford, 1982, pp. 1-35. 
[3] A.K. Tiwari, G.N. Tiwari, Effect of the condensing cover's slope on internal heat and mass transfer in distillation: an indoor simulation, Desalination 180, 2005, pp. 73-88.

[4] A.K. Tiwari, Annual performance of solar stills for different inclinations of condensing covers and water depths. PhD Thesis, Centre for Energy Studies, IIT Delhi, New Delhi, India, 2006.

[5] R.V. Dunkle, Solar Water Distillation: The Roof Type Still and a Multiple Effect Diffusion Still, Int. Development in Heat Transfer. ASME proceedings, 1961(part5), pp. 895-902.

[6] P.I. Cooper, The maximum efficiency of single-effect solar stills, Solar Energy 15, 1973, pp. 205-214.

[7] P.T. Tsilingiris, Modeling heat and mass transport phenomena at higher temperatures in solar distillation systems - The Chilton-Colburn analogy , Solar Energy 84, 2010, pp. 308-317.

[8] V.K. Dwivedi, G.N. Tiwari, Annual energy and exergy analysis of single and double slope passive solar stills, Applied Science Research 3(3), 2008, pp. 225-241.

[9] V.K. Dwivedi, Performance study of various designs of solar still. PhD Thesis: Centre for Energy Studies, IIT Delhi, New Delhi, India: 2009.

[10]Z. Hongfei, Z. Xiaoyan, Z. Jing, W. Yuyuan, A group of improved heat and mass transfer correlations in solar stills, Energy Convers. Mgmt. 43, 2002, pp. 2469-2478.

[11] J. C. Torchia- Núñez, M. A. Porta-Gándara, J.G. Cervantes-de Gortari, Exergy analysis of a passive solar still, Renewable energy 33(4), 2008, pp. 608-616.

[12]R. Dev, G.N. Tiwari, Characteristic equation of a passive solar still, Desalination 245, 2009, pp. 246-265.

[13]R. Dev, H.N. Singh, G.N. Tiwari, Characteristic equation of double slope solar still, Desalination 267, 2011, pp. 261-266.

[14]E. Rubio, M.A. Porta, J.L. Fernanadez, Cavity geometry influence on mass flow rate for single and double slope solar stills. Applied Thermal Engineering 20, 2000, pp. 11051111.

[15]E. Rubio, J.L. Fernandez, M.A. Porta-Gandara, Thermal performance of the condensing cover in a triangular solar still, Renewable Energy 29, 2004, pp. 895-906.

[16] G.N. Tiwari, Y.P. Yadav, comparative designs and long term performance of various designs of solar distillery, Energy Convers. Mgmt 27(3), 1987, pp. 327-333.

[17]M. Sathivel, S. Shanmugasundaram, Effect of energy storage medium (black granite gravel) on the performance of a solar still, Int. J. of Energy Research 32, 2008, pp. 68-92.

[18]A.K. Singh, G.N. Tiwari, Performance study of double effect distillation in a multiwick solar still. Energy Convers. Mgmt 33 (3), 1992, pp. 207-214.

[19]A. Kumar, J.D. Anand, Modelling and performance of a tubular multiwick solar still. Energy 17 (11), 1992, pp. 1067-1071.

[20]A. Hepbasli, A key review on exergetic analysis and assessment of renewable energy resources for a sustainable future, Renewable and Sustainable Energy Reviews 12, 2008, pp. 593-661. 